\title{
FENOMENA PERKEMBANGAN TARI NIRBAYA KARYA SETYASTUTI
}

\author{
Kurnia Rahmadhani; Rina Martiara; Budi Astuti
}

Juusan Tari, Fakultas Seni Pertunjukan, Institut Seni Indonesia Yogyakarta Email: kurniaa.nr@gmail.com; martiararina@isi.ac.id; budiastuti.tari@gmail.com

\begin{abstract}
ABSTRAK
Tari Nirbaya karya Setyastuti, merupakan sebuah karya tari yang terinspirasi dari 'edan-edanan'. 'Edan-edanan' merupakan rangkaian upacara yang harus ada saat ritual upacara temanten agung di Kraton Yogyakarta. Proses terciptanya tari Nirbaya diawali saat Setyastuti melihat secara langsung rangkaian upacara perkawinan yaitu 'edan-edanan' dalam prosesi pernikahan GBPH Cokroningrat, yaitu putra Sri Sultan Hamengkubuwana IX. Keberadaan 'edan-edanan' dalam upacara temanten agung Kraton Yogyakarta merupakan sebuah ritual adat yang berfungsi sebagai penolak bala. Figur yang unik yang bertugas sebagai cucuk lampah dan diperankan oleh abdi dalem khusus yang dipercayai dapat mengusir hal-hal gaib yang dapat menganggu acara. Nirbaya dalam bahasa Jawa yang artinya ora ana alangan; ora ana bebaya (tidak ada halangan; tidak ada bahaya), sehingga kata Nirbaya dapat diterjemahkan sebagai sesuatu untuk menolak bahaya atau menghalau dari yang sifatnya negatif. Ditarikan oleh sepasang penari laki-laki dan perempuan, dengan tidak melupakan esensi gerak tari gaya Yogyakarta yang dirancang dengan nuansa komikal yang diwarnai gerak-gerak improvisasi.Terinspirasi dari tradisi itulah, tari Nirbaya diciptakan untuk mewakili Daerah Istimewa Yogyakarta dalam rangka Festival Tari Nusantara pada tanggal 31 Desember 1989. Dalam perspektif fenomenologi penelitian ini menampakkan sebuah fenomena kondisi faktual di masyarakat, setelah tari Nirbaya dipentaskan di Jakarta menampakkan tari Nirbaya tetap difungsikan untuk keperluan upacara pernikahan dan berkembang sampai sekarang. Dalam berbagai peristiwa tersebut menampakkan unsur gerak improvisasi, menyebabkan terjadinya perubahan sesuai dengan kreativitas penarinya. Perubahan yang mencolok adalah pada gerak improvisasi, pelaku, pola lantai, penari, rias dan busana sehingga bentuk penyajiannya mengalami perubahan.
\end{abstract}

Kata Kunci: Tari Nirbaya, penyajian, fenomena 


\begin{abstract}
ABASTRACT
Nirbaya dance by Setyastuti, is a new dance work inspired by 'edan-edanan'. 'edan-edanan' is a series of ceremonies that must be present during the ritual of the temanten agung ceremony, especially at the Yogyakarta Palace. The creation process of the Nirbaya dance began when Setyastuti saw firsthand the series of wedding ceremonies, namely 'edan-edanan' in the wedding procession of GBPH Cokroningrat, the son of Sri Sultan Hamengkubuwana IX. The existence of 'edan-edanan' in the ceremony of temanten agung Kraton Yogyakarta is a traditional ritual that functions as a repellent to disaster. The unique figure who serves as a cucuk lampah and is played by the abdi dalem, specifically becomes the figure of a lunatic who is often called 'edan-edanan' '. This figure portrays a figure as 'edan-edanan' just acting, but not crazy. It is the form of a madman that is believed to be able to ward off magical things that can interfere with the event. According to Setyastuti, 'edan-edanan' is a unique figure, when a dance is made it looks interesting without forgetting the nuances of classical dance in Yogyakarta style and the nuances of the rituals of the great temanten ritual in the Yogyakarta Palace. Inspired by this tradition, Setyastuti finally created the Nirbaya dance in the framework of the Festival Tari Nusantara in Jakarta representing the Special Region of Yogyakarta on December 31, 1989. Nirbaya is in Javanese which means ora ana alangan; ora ana bebaya (no obstruction; no danger), so that the word Nirbaya can be translated as something to reject danger or drive away from negative things. Danced by a pair of male and female dancers, not forgetting the essence of Yogyakarta-style dance movements designed with comical nuances tinged with improvised movements. In a phenomenological perspective, this research shows a phenomenon of factual conditions in society, after the Nirbaya dance was staged in Jakarta, it shows that the Nirbaya dance is still used for the purposes of wedding ceremonies and is developing until now. In various events, the elements of improvisational motion are seen, causing changes to occur according to the creativity of the dancers. The striking changes are in the improvisation movement, actors, floor patterns, dancers, make-up and clothing so that the form of presentation changes.
\end{abstract}

Keywords: Nirbaya Dance, presentation, phenomenon 


\section{PENDAHULUAN}

Tari Nirbaya terinspirasi dari edanedanan yang merupakan sebuah rangkaian upacara temanten agung Kraton Yogyakarta, yang pada hakikatnya berfungsi sebagai sarana ritual menolak bala. Edan-edanan pada upacara ini merupakan sajen dan sangat sakral. Berawal dari melihat secara langsung tradisi edan-edanan dalam prosesi pernikahan GBPH Cokrodiningrat, putra Sri Sultan Hamengkubuana IX. Setyastuti ingin mencoba mengekspresikan figur edan-edanan yang mengawal ritual temanten yang bersifat penting dan harus ada tersebut.

Berangkat dari rangsang visual, suatu rangsang yang dapat didefinisikan sebagai sesuatu yang timbul dari gambar, patung, obyek, pola, wujud, dan sebagainya membangkitkan fikir semangat, dan mendorong kegiatan. Dari sosok edan-edanan munculah inspirasi pada diri Setyastuti untuk membuat koreografi baru yang geraknya mengacu pada teknik tari gaya Yogyakarta. Setyastuti tidak membicarakan perihal tari klasik gaya Yogyakarta, namun hanya memunculkan spiritnya. Menurut Setyastuti mengacu pada tari klasik gaya Yogyakarta bukan berarti harus memunculkan tekniknya namun bisa saja hanya menyerap spiritnya (Wawancara Setyastuti: 2020). Setyastuti mencoba untuk mengembangkan dan melebih- lebihkan geraknya, yang dalam bahasa koreografi disebut distorsi.

Nirbaya dalam bahasa Jawa yang artinya ora ana alangan; ora ana bebaya (tidak ada halangan; tidak ada bahaya) (Tim Penyusun Balai Bahasa Yogyakarta. 2000: 539), sehingga kata Nirbaya dapat diterjemahkan sebagai sesuatu untuk menolak bahaya atau menghalau dari yang sifatnya negatif (Wawancara Setyastuti: 2020). Menolak bahaya yang dimaksud, bahaya dalam kehidupan berumah tangga atau kehidupan apapun bentuknya, sehingga menciptakan kehidupan yang diharapakan. Judul tari ini dicetuskan oleh Setyastuti saat berjalan melewati Plengkung Gading yaitu salah satu pintu gerbang untuk memasuki wilayah Kraton yang terdapat tulisan Nirbaya. Judul tersebut memiliki arti bersih-bersih yang berfungsi sebagai tolak bala atau mencegah dari sesuatu malapetaka dan kemalangan.

Tari Nirbaya yang biasa ditarikan oleh sepasang penari laki-laki dan perempuan dengan berdandan layaknya seperti temanten, beserta rias wajah yang terkesan lucu dengan menggunakan singwid. Biasa dipentaskan dalam upacara perkawinan adat Yogyakarta. Tari Nirbaya telah mengalami fenomena perkembangan dalam bentuk penyajian dan perubahan fungsi di dalam upacara perkawinan adat Yogyakarta. Fenomena 
perkembangan yang terjadi dalam bentuk penyajian terdiri dari tema, pelaku, gerak, rias, busana, iringan, pola lantai. Fenomena perkembangan ini telah mengalami perubahan baik positif maupun negatif. Perubahan dari sisi positif yang terjadi adalah sebuah kretivitas pelaku tari Nirbaya dalam bentuk rias dan busana. Namun, dari sisi negatif bentuk penyajian tidak sesuai dengan bentuk penyajian yang sesungguhnya saat Setyastuti menciptakan tari Nirbaya.

\section{PEMBAHASAN}

Fenomena yang terjadi pada tari Nirbaya saat ini adalah perkembangan yang dapat dilihat secara visual atau perubahan dalam bentuk penyajian, dan perkembangan yang tidak terlihat secara visual, yakni fungsi dan makna tari Nirbaya di dalam upacara perkawinan adat Yogyakarta. Diskusi tentang perubahan objek seni tidak hanya menyangkut munculnya perubahan bentuk, namun dapat diperlebar pada terjadinya perubahan fungsi. Hal ini didasari konsep pemikiran apabila masyarakat pemiliknya berubah, maka fungsinya juga berubah (Supadma, 2018: 140). Maka munculnya fungsi baru tari Nirbaya sangat tergantung pada orientasi fungsi yang dikehendaki oleh masyarakat pengelolanya.

Memang saat ini tari Nirbaya sudah mengalami fenomena perkembangan sangat pesat khususnya di upacara temanten atau acara hiburan lainnya. Fenomena perkembangan yang terjadi di masyarakat dirasa sangat pesat, jauh melampaui sejak diciptakannya tari Nirbaya. Perkembangan ini dirasa ke arah yang positif maupun negatif. Sebuah karya tari yang diciptakan sejak tahun 1989 hingga sekarang sudah berusia 31 tahun, secara bentuk pertunjukan tentu telah memiliki pola-pola yang pasti. Selain itu tari ini juga telah menemukan fungsinya di masyarakat baik sebagai pelaku pertunjukan, penanggap atau pemangku hajad, maupun masyarakat penonton pada umumnya.

Penelitian ini mengarah pada beberapa aspek, yaitu masyarakat awam ataupun pemangku hajad, pelaku seni, dan masyarakat lain. Masing-masing dari aspek tersebut terdapat fenomena yang berbeda-beda. Masyarakat awam atau pemangku hajad biasanya menginginkan sebuah pertunjukan tari Nirbaya yang meriah dan atraktif, seperti dari segi gerak, pelaku, iringan, pola lantai, dan busana yang dipakai. Karena dengan suasana yang meriah masyarakat sangat antusias untuk menyaksikan dan menginginkan tari Nirbaya dipentaskan kembali. Fenomena yang terjadi pada pelaku seni yang membawakan tari Nirbaya, biasanya dibawakan secara berlebihan dari aspek gerak dan pelakunya.. Masyarakat lain membawakan bentuk penyajian tari Nirbaya 
FENOMENA PERKEMBANGAN

TARI NIRBAYA KARYA SETYASTUTI

secara bebas, hanya sebatas sepengetuhan masyarakat lain bahwa tari Nirbaya adalah tarian yang tidak terstruktur karena berpijak dari kata edan-edanan sehingga dibawakan secara bebas. Dari ketiga aspek tersebut terdapat juga fenomena yang berbeda dalam membawakan tari Nirbaya. Namun fenomena yang paling mencolok dari perubahan ini adalah pada pelaku pertunjukan. Saat ini tari Nirbaya sering ditarikan oleh sesama jenis, yaitu laki-laki dan laki-laki, di mana salah seorang penari berdandan sebagai Nyi Sarana (cross gender). Di masyarakat awam hal ini justru dianggap sebagai sajian yang menarik dan meriah. Untuk pelaku, fenomena ini dianggap menguntungkan dari segi ekonomi, karena makin banyak masyarakat yang menanggap tari Nirbaya sebagai pemeriah suasana pesta pernikahan.

Keberadaan tari sejatinya tidak berdiri sendiri sebagai ungkapan kreativitas penciptanya. Tari memiliki nilai tertentu dalam kehadirannya di masyarakat. Tari Nirbaya, sebagai ungkapan kreativitas Setyastuti juga tidak bisa dilepaskan dalam kehidupan sosial masyarakatnya itu sendiri. Dinamika kehidupan sosial masyarakat inilah yang selanjutnya melahirkan nilai yang ada pada tari Nirbaya, yaitu cara pandang mereka menilai dan menerima kehadirannya sehingga tari Nirbaya dapat berkembang hingga saat ini.
JOGED: Jurnal Seni Tari p-ISSN 1858-3989 | e-ISSN 2655-3171

Baik di masyarakat awam ataupun kalangan seniman itu sendiri.

Ukuran etika dapat dipakai guna memahami dan mengerti cara manusia harus mengikuti ajaran moral tertentu, atau cara mengambil sikap yang bertanggung jawab berhadapan dengan berbagai ajaran moral (Y. Sumandyo Hadi, 2019: 53). Dalam fenomena perkembangan bentuk penyajiannya, terdapat perkembangan yang dirasa kurang pas dan tidak sesuai dengan tujuan awal diciptakannya Tari Nirbaya oleh Setyastuti.

\section{A. Perubahan Bentuk Penyajian}

\section{Tema}

Tari Nirbaya bertema ritual tetapi semu atau tidak memiliki ritual yang utuh. Karena jika dikatakan tari ritual, tari Nirbaya harus ada disebuah upacara temanten dalam prosesi upacara pernikahan masyarakat umum. Keberadaan tari Nirbaya bukan merupakan sesuatu yang baku atau tidak menjadi sebuah keharusan untuk diadakan atau dipentaskan. Seperti halnya tradisi edanedanan sebagai rangkaian di ritual upacara temanten yang baku dan harus ada yang ada di Kraton Yogyakarta khususnya. Tari Nirbaya memang mengarah dari tradisi edan-edanan, tetapi tari Nirbaya tidak seutuhnya menjadi tari ritual tapi bisa saja menjadi tari hiburan. 


\section{Pelaku}

Terdapat fenomena yang berkembang perihal pelaku tari Nirbaya saat ini. Fenomena cross-gender, yaitu fenomena silang peran gender, baik dalam kehidupan sehari-hari maupun dalam kehidupan seni pertunjukan. (Didik Nini Thowok, 2005: 41). Salah satunya adalah penari perempuan tari Nirbaya yang figurnya bernama Nyi Sarana yang seharusnya dilakukan oleh penari perempuan ditarikan oleh penari laki-laki yang berbusana dan berias seperti perempuan, biasa orang menyebutnya croos gender. Cross gender atau silang gender adalah karakter perempuan diperankan laki-laki, atau karakter laki-laki diperankan perempuan (Didik Nini Thowok, 2005: 41) Peran Nyi Sarana yang dilakukan didalam tari Nirbaya kebanyakan besar yang dilakukan oleh penari yang berjenis kelamin laki-laki, padahal sesungguhnya diperankan oleh penari berjenis kelamin perempuan.

\section{Peran figur Nyi Sarana yang} diperankan oleh penari berjenis kelamin lakilaki, banyak masyarakat awam menganggap lebih lucu diperankan oleh penari laki-laki, karena kebanyakan besar masyarakat menganggap tari Nirbaya lebih meriah daripada diperankan penari berjenis kelamin perempuan.

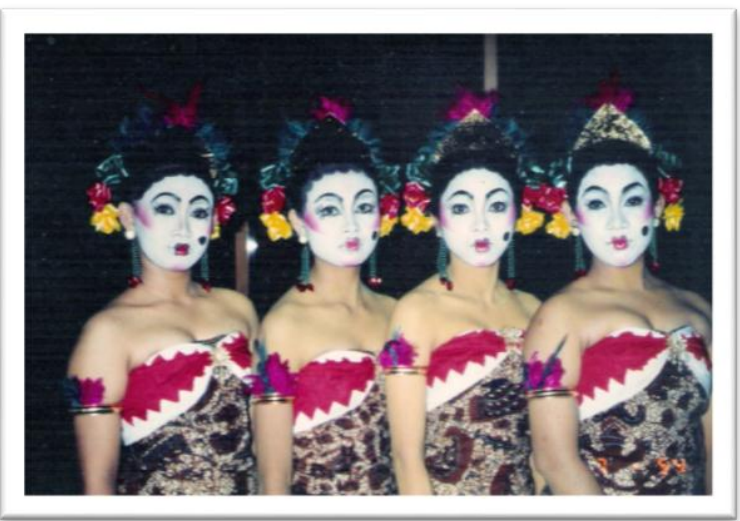

Gambar 1. Empat penari yang memerankan figur $N y i$ Sarana dalam mementaskan Festival Tari Nusantara di Jakarta tahun 1989

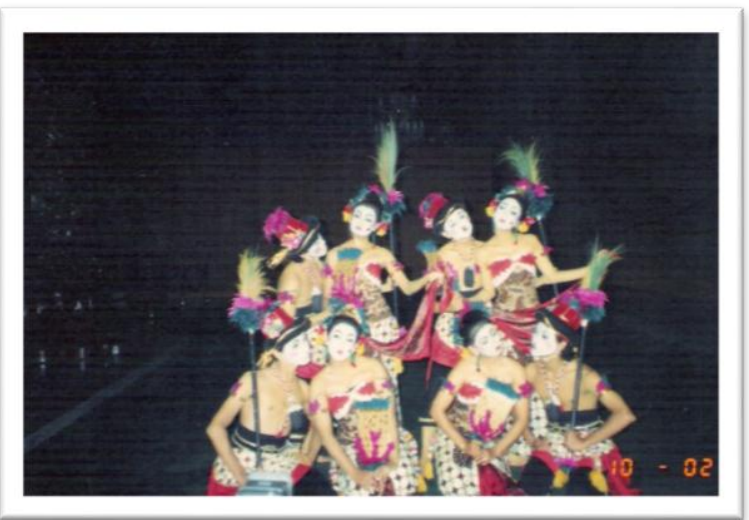

Gambar 2: Empat pasang penari Nirbaya pertama kali, saat maju mewakili DIY (dok. Setyastuti 2020)

\section{Gerak}

Gerak tari Nirbaya memang terlihat lucu karena segi gerak dibuat berlebihan (hiperbola), sehingga banyak masyarakat senang menanggap atau melihat tari Nirbya saat dipentaskan. Koreografi yang dibawakan pelaku tari Nirbaya terkadang dibuat lucu untuk menghibur penonton, karena terkadang pemangku hajad yang menanggap menginginkan suasana yang meriah supaya para penonton juga merasa terhibur. 
Tari Nirbaya sudah memiliki bentuk koreografi yang pasti dan tidak ada penambahan aksen-aksen gerak yang lain, bahkan terkadang gerak tari Nirbaya yang sesungguhnya ditambah dengan gerak improvisasi atau acrobatic. Penambahan gerak improvisasi atau acrobatic yang dilakukan oleh pelaku tari Nirbaya untuk membangun suasana yang lebih meriah supaya para penonton merasa terhibur dengan adanya gerak-gerak tersebut.

\section{Iringan}

Iringan didalam tari Nirbaya telah menggunakan instrumen gamelan, ketika tari Nirbaya dipentaskan iringan bisa menggunakan gamelan secara langsung maupun tidak. Fenomena yang sering terjadi ketika menggunakan iringan secara langsung, wiyaga menambahkan aksen musik improvisasi supaya semakin meriah.

\section{Rias}

Tata rias pada tari Nirbaya tidak lagi bertujuan untuk mendapatkan kesan jelek layaknya orang gila. Pengembangan tata riasnya melahirkan kesan lucu. Hal ini sesuai dengan tata rias yang telah dikonsepsikan oleh Setyastuti yaitu mengacu pada tata rias badut yang berkesan lucu. Sejak awal diciptakannya tari Nirbaya hingga sekarang banyak sekali fenomena perkembangan rias, semua itu tergantung dari masing-masing pelaku tari
Nirbaya yang semakin kreatif dalam mengembangkan rias.

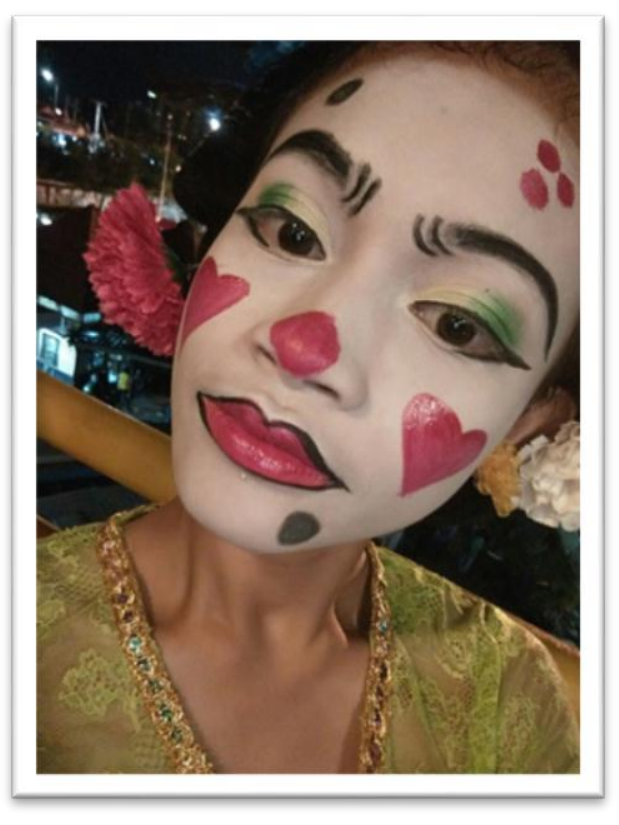

Gambar 3. Nia sebagai pelaku tari Nirbaya yang memerankan figur Nyi Sarana dengan perkembangan rias menggunakan singwid berwarna hijau gradasi bagian mata. (dok. Kurnia 2017)

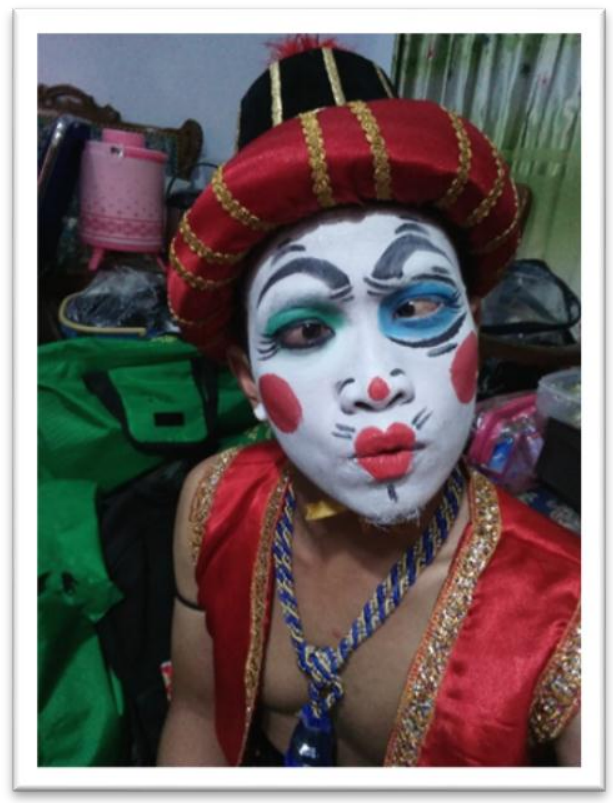

Gambar 4. Afriza sebagai pelaku tari Nirbaya yang memerankan figur Ki Sarana dengan perkembangan rias menggunakan singwid berwarna biru dan hijau pada bagian mata. (dok. Kurnia 2017) 
JOGED: Jurnal Seni Tari

p-ISSN 1858-3989 | e-ISSN 2655-3171

\section{Busana}

Busana yang tetap berpijak pada tradisi edan-edanan yang ada di Kraton Yogyakarta. Busana yang digunakan oleh pelaku tari Nirbaya hingga saat ini telah mengalami fenomena perkembangan. Perkembangan ini telah mengunggah pelaku seni sehingga kreativ dalam pengembangan kostum dengan beragam jenis kostum tari Nirbaya yang dimiliki secara pribadi.

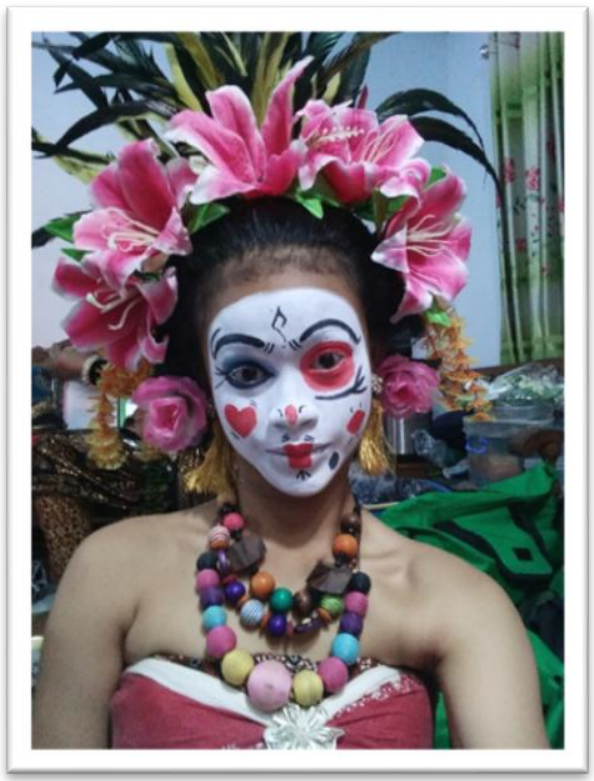

Gambar 5. Nia sebagai figur Nyi Sarana menggunakan aksesoris bunga korsase hingga menutupi bagian sunggar dan menggunakan bulu kemoceng pada bagian sanggul.

(dok. Kurnia 2017)
FENOMENA PERKEMBANGAN TARI NIRBAYA KARYA SETYASTUTI

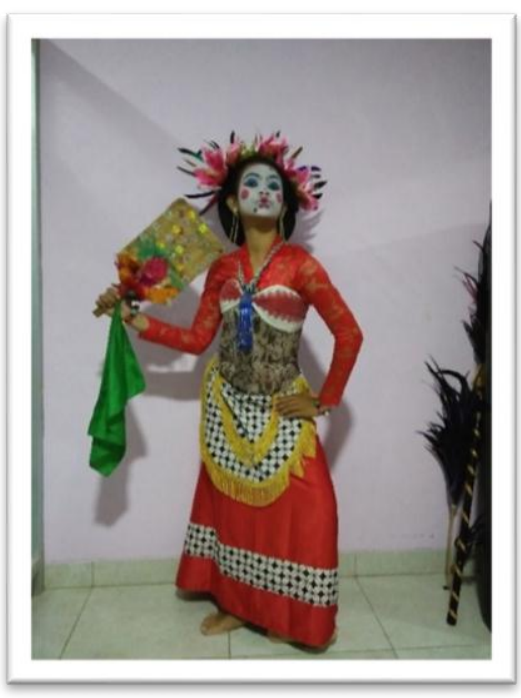

Gambar 6. Penari Nirbaya yang memerankan Nyi Sarana menggunakan kebaya berwarna merah sebelum memakai semekan.

(dok. Kurnia 2017)

\section{Pola Lantai}

Pola lantai yang terdapat pada tari Nirbaya sudah memiliki bentuk pola lantai yang pasti. Pola lantai dengan bentuk putaran dan zig-zag merupakan pola lantai yang sudah dikoreografikan oleh Setyastuti. Pola lantai yang dilakukan oleh pelaku tari Nirbaya secara berlebihan dengan memperlihatkan gerak atau ekspresi wajah dengan di depan kamera, tidak hanya kamera dari pihak mempelai yang menyewakan. Namun, nampak di depan kamera ketika para tamu membuat insta story di aplikasi whatsapp maupun instagram. Bahkan terkadang bermain pola lantai dibelakang keluarga mempelai, seperti menggoda-goda tamu yang sudah datang maupun menggoda anak kecil sampai menangis. 


\section{B. Perubahan Fungsi Tari Nirbaya Karya Setyastuti dalam Upacara Perkawinan Adat Yogyakarta}

Tari yang menjadi bagian dari upacara perkawinan adat Yogyakarta adalah tari Nirbaya, tarian ini juga bisa dikatakan merupakan satu rangkaian dengan upacara perkawinan adat Yogyakarta setelah upacara panggih atau temu manten. Pada upacara panggih, kedua mempelai dipertemukan setelah akad nikah dilaksanakan, untuk kemudian disandingkan ke pelaminan. Tari Nirbaya dipentaskan setelah upacara panggih kemudian menjadi cucuk lampah hingga sampai ke tempat pelaminan.

Tari Nirbaya merupakan sajen ketika menjadi satu rangkaian dalam upacara adat perkawinan Yogyakarta. Posisi penari Nirbaya saat upacara panggih memang berpindahpindah, penari membersihkan terlebih dahulu tempat pelaminan kemudian menarikan tari Nirbaya di depan kedua mempelai setelah pintu masuk menuju tempat pelaminan. Komposisi seperti ini memang sudah menjadi keharusan dalam menarikan tari Nirbaya setelah upacara panggih. Berpindahnya penari Nirbaya guna membersihkan hal-hal yang buruk supaya acara dapat berjalan lancar.

Tari Nirbaya juga bisa saja dipentaskan bukan bagian dari upacara perkawinan, namun dalam hal ini bukan merupakan dari bagian sajen atau ritual, hanya sebagai seni pertunjukan yang sifatnya entertaint. Ketika dipentaskan bukan sebagai bagian dari upacara panggih, mungkin dipentaskan saat pertengahan acara maupun akhir acara. Ketika mengisi bukan bagian dari upacara perkawinan memang menjadi tari hiburan, bukan lagi menjadi tari ritual maupun menjadi sajen.

Tari Nirbaya memang tarian untuk menolak bala, apalagi tarian ini sangat cocok dipentaskan saat acara perkawinan. Mungkin tidak hanya perkawinan adat Yogyakarta, sekarang sudah banyak dijumpai disetiap acara perkawinan menggunakan tarian tersebut. Setyastuti mengatakan bahwa masyarakat sekarang memandang tari Nirbaya merupakan tari klasik gaya Yogyakarta dan menjadi bagian dari upacara perkawinan adat Yogyakarta. Namun menurut Setyastuti tari ini tidak hanya menjadi bagian dari upacara perkawinan adat Yogyakarta, karena bisa saja dipentaskan di mana saja. Asalkan tetap menggunakan kaidah-kaidah yang berlaku di Kraton Yogyakarta (Wawancara Setyastuti: 2020).

Tari Nirbaya memang tarian menolak bala, tarian ini sudah banyak dikenal di masyarakat luas. Fungsi dari tari sebagai menolak bahaya dalam acara perkawinan adat Yogyakarta, namun khususnya ketika sebagai rangkaian dalam upacara adat perkawinan Yogyakarta. Di luar konteks tersebut, tari 
Nirbaya memang menjadi penolak bala. Namun, sifatnya hanya sebagai tari hiburan yang hanya menceritakan sebagai menolak bahaya bukan seutuhnya menjadi penolak bahaya yang menjadi sajen maupun ritual.

Seni yang harus mengalami perubahan fungsi dan tampilannya seiiring dengan jiwa zaman memang kemudian tampil manifestasi ekspresi yang tidak lagi "harus" menyesuaikan diri dengan kisi-kisi arsitektural ruang. Ruang kekinian telah memberikan kesadaran baru pada fleksibilitas dan kebebasan yang tidak lagi berbasis pada pendekatan untuk semata (F.X Widaryanto, 2015: 36).

\section{Fungsi Ritual}

Fungsi ritual Tari Nirbaya dalam beragam kehadirannya dalam berbagai kegiatan yang dilakukannya adalah sebagai penolak bala dari semua acara yang diselenggarakan. Orang masih percaya bahwa Tari Nirbaya akan mengusir bala yang dianggap akan mengganggu jalannya upacara, Mengusir bala yang akan mengganggu hubungan keluarga pengantin, serta mengusir bala yang akan mengganggu hubungan rumah tangga pengantin baru nantinya.

Selanjutnya fungsi ritual ini mulai bergeser menjadi fungsi hiburan. Kehadiran tari Nirbaya di dalam upacara perkawinan adat Yogyakarta umumnya menjadi pemeriah suasana, seperti dari gerak dan pelaku. Karena dari kedua aspek tersebut terdapat fenomena yang sering dijumpai dalam upacara perkawinan adat Yogyakarta, dari segi gerak yaitu ketika pelaku menambahkan gerakan improvisasi maupun acrobatic dengan tidak sesuai bentuk koreografi aslinya. Pelaku yang yang terjadi dalam fungsi ritual ini adalah pelaku cross gender, dimana pelaku cross gender ini memerankan figur Nyi Sarana yang diperankan oleh penari berjenis kelamin lakilaki dengan berias dan berkostum seperti layaknya penari perempuan. Karena dengan adanya fenomena tersebut tari Nirbaya sering dipentaskan dan dibutuhkan oleh pemangku hajad, karena sangat membangun suasana dan juga ditambhkan aksen teriakan dari penari Nirbaya.

\section{Fungsi Sosial}

Fungsi sosial yang terdapat pada tari Nirbaya baik pelaku tari maupun wiyaga adalah fungsi ekonomi untuk memenuhi kebutuhan hidup mereka, dimana dalam menyajikan tari Nirbaya ini sering sekali dipentaskan dalam acara perkawinan maupun hiburan yang lainnya. Ciri khas dari gerak, iringan, rias, dan busana sangat membuat para penonton maupun penanggap sangat menyukai tari Nirbaya. Sehingga dalam penyajian ini sangat dibutuhkan juga untuk pelaku tari dan wiyaga untuk memenuhi kebutuhan ekonomi terutama dalam hari 
FENOMENA PERKEMBANGAN

TARI NIRBAYA KARYA SETYASTUTI

liburan sabtu dan minggu maupun hari lainnya.

Bagi orang yang menanggap atau pemangku hajad pertunjukan tari Nirbaya bisa menaikkan derajat mereka. Hal ini dikarenakan ada efek gengsi status sosial. Hanya orang yang punya uang yang bisa mementaskan tari Nirbaya. Namun, tidak hanya itu biasa pemangku hajad juga bernegoisasi dengan penari perihal honorer. Karena dengan bernegoisasi pelaku tari Nirbaya dapat memperhitungkan dari biaya transportasi, busana, dan jam terbang dari masing-masing pelaku tari Nirbaya.

Biasanya banyak orang yang akan memperbincangkan kemeriahan pesta dengan kelucuan hiburan di dalamnya, sehingga si pemangku hajad berani menambahkan honor untuk penari jika mampu membuat suasana semakin semarak. Karena dengan penambahan honor tersebuat pelaku tari juga semakin semarak dan semangat dalam pembawaan tari Nirbaya, selain itu juga memuaskan pemangku hajad supaya besok bisa dihubungi kembali untuk menarikan tari Nirbaya.

\section{Fungsi Estetis}

Nilai-nilai estetis yang terdapat dalam tari Nirbaya perkembangan rias, busana, musik, gerak yang direlasikan dengan nilai Jawa (Yogyakarta) menyimbolkan estetika
JOGED: Jurnal Seni Tari p-ISSN 1858-3989 | e-ISSN 2655-3171

budaya Yogyakarta. Karena dari aspek gerak yang masih berpijak pada gerak tari klasik gaya Yogyakarta yaitu spitritnya, iringan yang berpijak pada iringan tari yang digunakan saat upacara perkawinan agung putra dan putri Kraton Yogyakarta, dan rias busana yang masih berpijak pada edan-edanan yang ada di Kraton Yogyakarta. Seperti jarik bermotif kawung berlatar putih sebagai ciri khas dari batik gaya Yogyakarta, sanggul tekuk sebagai ciri khas dari Yogyakarta, dan berbagai macam aksesoris yang masih berpijak pada edan-edanan.

\section{PENUTUP}

Tari Nirbaya karya Setyastuti merupakan sebuah karya tari baru yang terinspirasi dari tradisi edan-edanan yang ada di Kraton Yogyakarta. Setyastuti menciptakan tari Nirbaya karena ingin membuat sebuah karya tari yang terlepas dari aturan baku yang terdapat pada tari klasik gaya Yogyakarta. Tetap terinspirasi dari gerak tari gaya Yogyakarta, namun hanya spiritnya. Sehingga koreografi yang diciptakan oleh Setyastuti menjadi berkembang dan bisa dikatakan dengan gerak dilebih-lebihkan (didistorsi) sehingga menimbulkan kesan lucu atau bersifat komikal. Dalam hal ini Setyastuti menginginkan supaya tari gaya Yogyakarta tidak menjadi sesuatu yang baku, supaya bisa dikembangkan menjadi lebih jauh lagi. 
Terinpirasi dari tradisi edan-edanan Setyastuti menciptakan tari Nirbaya dengan tidak meninggalkan aturan-aturan yang baku di dalam Kraton Yogyakarta. Setyastuti bersusah payah mengeluarkan tema tersebut, dengan tetap mengacu dari tradisi ritual temanten yang ada di Kraton Yogyakarta. Tradisi edan-edanan pada upacara temanten keraton Yogyakarta, memang bukan sebuah koreografi, namun hanya sebagai cucuk lampah, yang berperan sebagai pengawal pengantin. Berangkat dari rangsang visual edan-edanan inilah yang membuat Setyastuti ingin menciptakan sebuah karya tari baru, akhrinya terciptalah tari Nirbaya untuk maju ke ajang Festival Tari Nusantara pada tahun 1989.

Banyak kritikan ketika Setyastuti menciptakan tari Nirbaya, namun kritik ini tidak membuatnya patah semangat. Setyastuti yang mempunyai sifat cuek dan tidak terlalu menghiraukan omongan-omangan yang menyakitkan hati. Namun dalam hal ini, Setyastuti ada yang mendukung seorang maestro tari yang bernama Bagong Kussudiardjo. Menurut Bagong Kusudiardjo tarian ini tetap Yogyakarta tetapi sudah dikembangkan. Kalimat seperti ini membuat Setyastuti tidak patah semangat dan tetap berangkat untuk mewakili DIY.

Terciptanya tari Nirbaya dari tahun 1989 hingga sekarang tahun 2020 sudah berusia 31 tahun. Sebuah karya tari yang sering dijumpai di acara perkawinan adat Yogyakarta maupun acara hiburan lainnya, telah terjadi banyak sekali fenomena perkembangan. Fenomena yang terjadi pada tari Nirbaya saat ini adalah perkembangan yang dapat dilihat secara visual atau perubahan dalam bentuk penyajian, dan perkembangan yang tidak terlihat secara visual, yakni fungsi dan makna tari Nirbaya di dalam upacara perkawinan adat Yogyakarta. Fenomena ini mengarah pada penelitian dari beberapa aspek yaitu masyarakat awam ataupun pemangku hajad, pelaku seni, dan masyarakat lain. Masing-masing dari aspek tersebut terdapat fenomena yang berbedabeda. Penelitian ini memakai pendekatan Fenomenologi, ilmu tentang penampakan (fenomena). Upaya hati-hati dalam mendeskripsikan hal-hal sebagaimana mereka menampakkan diri ke dalam kesadaran. Dengan kata lain, semua persoalan tentang semesta luar harus didekati dengan senantiasa melibatkan cara penampakan mereka pada kesadaran manusia.

Fenomena seperti ini ada positif maupun negatif, fenomena yang sering terjadi karena kurangnya wawasan pelaku yang membawakan tari Nirbaya. Fenomena yang berkembang hingga sekarang memang mengunggah semangat kreativitas dari pelaku 
FENOMENA PERKEMBANGAN

TARI NIRBAYA KARYA SETYASTUTI

seni, namun dalam hal ini kreativitas

terkadang menjadi berlebihan.

\section{DAFTAR SUMBER ACUAN}

\section{A. Sumber Tercetak}

Brown, A.R. Radcliffe. 1980. Struktur dan Fungsi dalam Masyarakat Primitf. Kuala Lumpur: Dewan Bahasa dan Pustaka Kementerian Pelajaran Malaysia.

Dibia, I Wayan. 2006. Tari Komunal. Jakarta: Lembaga Pendidikan Seni Nusantara.

Hadi, Y. Sumandyo. 2013. Seni Pertunjukan dan Masyarakat Penonton. Yogyakarta: Cipta Media.

Hadi, Y. Sumandyo. 2017. KoreografiBentuk-Teknik, Isi. Yogyakarta: Cipta Media.

Hadi, Y. Sumandyo. 2017. Koreografi, Ruang Proscenium. Yogyakarta: Cipta Media.

Hadi, Y. Sumandyo. 2019. Ruang Kreatif dalam Pengkajian, Penciptaan, dan Pendidikan Seni. Yogyakarta: BP ISI Yogyakarta.

Hersapandi. 2014. Ilmu Sosial Budaya Sebuah Pengantar. Yogyakarta: Badan Penerbit ISI Yogyakarta.

Hersapandi. 2015. Ekspresi Seni Tradisi Rakyat dalam Perspektif Transformasi Sosial Budaya. Badan Penerbit ISI Yogyakarta.
JOGED: Jurnal Seni Tari p-ISSN 1858-3989 | e-ISSN 2655-3171

Hersapandi. 2017. Metode Penelitian Tari. Yogyakarta: Badan Penerbit: ISI Yogyakarta.

Holt, Claire. 2000. Melacak Jejak Perkembangan Seni di Indonesia. Arti Line: Bandung. (terjemahan RM. Soedarsono)

Kutoyo, Sutrisno. 1976. Sejarah Daerah Istimewa Yogyakarta. Yogyakarta: Departemen Pendidikan dan Kebudayaan.

Moleong, Lexy J. 2012. Metodologi Penelitian Kualitatif. Bandung: Remaja Rosdakarya.

Mochtar, Kusniati. 1988. Adat Perkawinan Kraton Yogyakarta Dalam Bahasa Kebesaran. Jakarta: Anjungan DIY TMII.

Murgiyanto, Sal. 2015. Pertunjukan Budaya dan Akal Sehat. Jakarta: Fakultas Seni Pertunjukan - IKJ (Institut Kesenian Jakarta)

Nini Thowok, Didik. 2005. Penari Cross Gender. Malang: Sava Media.

Nuraini, Indah. 2011. Tata Rias dan Busana Wayang Orang Gaya Surakarta. Yogyakarta: ISI Yogyakarta.

Ritzer, George. 2014. Sosiologi Ilmu Pengetahuan Berparadigma Ganda. Terjemahan Alimandan. Jakarta: PT.Raja Grafindo Persada.

Smith, Jacqueline. 1985. Komposisi Tari Sebuah Pertunjukan Praktis Bagi Guru (terjemahan Ben Suharto, S.ST). Yogyakarta: Ikalasti

Soedarsono. 1992. Pengantar Apresiasi Seni. Jakarta: Balai Pustaka. 
Soedarsono, R.M. 1999. Seni Pertunjukan dan Pariwisata (Rangkuman Esai Tentang Seni Pertunjukan Indonesia dan Pariwisata). Yogyakarta: BP ISI Yogyakarta.

Sugiono. 2016. Metode Penelitian Kuantitatif, Kualitatif, dan $R \& D$. Bandung: Alfabeta.

Sumaryono. 2007. Jejak dan Problematika Seni Pertunjukan Kita. Yogyakarta: Prasista.

Sumaryono. 2016. Antropologi Tari dalam Perspektif Indonesia. Yogyakarta: Media Kreativa Yogyakarta.

Supadma. 2018. Wayang Wong Pedhalangan: Fenomena Perkembangan Wayang Wong di Luar Istana. Yogyakarta. Taman Budaya Yogyakarta.

Supardjan \& I Gusti Ngurah Supartha. 1980. Pengantar Pengetahuan Tari. Jakarta: CV. Sandang Mas.

Suwondo, Bambang. 1978. Adat dan Upacara Perkawinan Daerah Istimewa Yogyakarta. Yogyakarta: Proyek Penelitian dan Pencatatan Kebudayaan Daerah.

Suyami. 2008. Upacara Ritual di Kraton Yogyakarta. Yogyakarta: Kepel Press.

Tim Penyusun Balai Bahasa Yogyakarta. 2000. Kamus Bahasa Jawa (Bausastra Jawa). Yogyakarta: Kanisius (Anggota IKAPI).

Trustho. 2005. Kendhang Dalam Tradisi Tari Jawa. Surakarta: STSI Press.

Widaryanto, F.X. 2015. Ekokritikisme Sardono W. Kusumo Gagagasan, Proses Kreatif, Teks-Teks Penciptannya. Jakarta: PascaIKJ.
Wibowo, Fred. 1981. Mengenl Tari Klasik Gaya Yogyakarta. Yogyakarta: Dewan Kesenian Prop-DIY.

\section{B. Narasumber}

Afiza Hindra Putra, selaku penari laki-laki tari Nirbaya, 25 tahun.

Gandung Djatmiko, sebagai penata iringan tari Nirbaya, 59 tahun, Dosen jurusan Pendidikan Seni Pertunjukan ISI Yogyakarta.

Guntur Sambodo, selaku penari cross gender, 28 tahun.

Sarjiwo, penari laki-laki tari Nirbaya, 59 tahun, Dosen jurusan Pendidikan Seni Pertunjukan ISI Yogyakarta.

Setyastuti, sebagai penata tari Nirbaya, 56 tahun, Dosen jurusan tari ISI Yogyakarta, Jalan Temugiring 12 RT 12, Sorowajan, Panggungharjo, Sewon, Bantul, Yogyakart

\section{Videografi}

Video pertunjukan tari Nirbaya dalam acara "Indonesian Cultural Performance" di Sri Lanka

\section{Webtografi}

https://myimage.id/tari-nirbaya/

https://jogjacreative.wordpress.com/tag/edanedanan/ 